\title{
Improved Learning Outcomes of Various Jobs through Powerpoint Media for Class IV Students of SD Terangmas
}

\author{
Kusmono \\ SD Terangmas \\ kusmonoahmad@gmail.com
}

\section{Article History}

accepted $14 / 11 / 2020$

approved $21 / 11 / 2020$

published 26/11/2020

\begin{abstract}
The purpose of this study was to improve student learning outcomes in thematic learning in grade IV SD. This research is a classroom action research (PTK) which is carried out in three cycles, each cycle consisting of planning, implementation, observation, and reflection stages. The subjects of this study were 14 grade students of SD Terangmas in the 2020/2021 academic year. Data collection techniques using observation and tests. Data analysis includes data reduction, data presentation, and drawing conclusions. Research shows that the use of learning powerpoint media can improve student learning outcomes in the subject matter of Theme 4 Sub Theme 2 Learning 1 in class IV Terangmas Undaan Elementary School for the 2020/2021 school year as evidenced by the percentage of learning outcomes in cycle I by $70 \%$ to $90 \%$ in the cycle II and becomes $100 \%$ in cycle III
\end{abstract}

Keywords: Learning Powerpoint, Thematic, Students

\section{Abstrak}

Tujuan penelitian ini adalah meningkatkan hasil belajar siswa pada pembelajaran tematik kelas IV SD. Penelitian ini merupakan penelitian tindakan kelas (PTK) yang dilaksanakan dalam tiga siklus, setiap siklus terdiri dari tahap perencanaan, pelaksanaan, observasi, dan refleksi. Subjek penelitian ini adalah peserta didik kelas IV SD Terangmas tahun pelajaran 2020/2021 yang berjumlah 14 peserta didik. Teknik pengumpulan data menggunakan observasi dan tes. Analisis data meliputi reduksi data, penyajian data, dan penarikan kesimpulan. Penelitian menunjukkan bahwa penggunaan media powerpoint pembelajaran dapat meningkatkan hasil belajar siswa pada materi Tema 4 Sub Tema 2 Pembelajaran 1 di kelas IV SD Terangmas Undaan tahun pelajaran 2020/2021 yang dibuktikan dengan persentase ketuntasan hasil belajar pada siklus I sebesar $70 \%$ menjadi $90 \%$ pada siklus II dan menjadi $100 \%$ pada siklus III Kata kunci: Powerpoint Pembelajaran,Tematik, Siswa

Social, Humanities, and Education Studies (SHEs): Conference Series https://jurnal.uns.ac.id/shes 


\section{PENDAHULUAN}

Belajar merupakan suatu proses yang terjadi pada semua orang dan berlangsung seumur hidup. Salah satu indikasi bahwa seseorang telah belajar adalah adanya perubahan tingkah laku dalam dirinya. Perubahan tingkah laku tersebut menyangkut perubahan yang bersifat pengetahuan (kognitif), keterampilan (psikomotor), dan perubahan nilai dan sikap (afektif). Perubahan yang terjadi pada tingkah laku tersebut merupakan perubahan yang bernilai positif. Sehingga tujuan dari belajar tersebut dapat tercapai dengan maksimal.

Dalam hal ini guru memerlukan ketrampilan dasar mengajar berupa adanya variasi mengajar siswa dan kemampuan merancang, mengimplementasikan berbagai strategi pembelajaran yang dianggap cocok dengan minat dan bakat serta sesuai dengan taraf perkembangan siswa. Agar siswa tidak merasa bosan, perhatiannya bertambah, dan pembelajaran yang dilaksanakan dapat tercapai. Dalam proses belajar mengajar ada variasi bila guru menunjukkan adanya perubahan dalam gaya mengajar, media yang digunakan berganti-berganti, dan ada perubahan dalam pola interaksi antara guru-siswa, siswa-guru, dan siswa-siswa. Kurangnya variasi guru dalam menggunakan media pembelajaran membuat siswa cepat bosan dan komunikasi dua arah kurang terlihat dalam pembelajaran.

Situasi dan kondisi ini terlihat jelas ketika guru melaksanakan pembelajaran pada Kelas 4 Tema 4 Subtema 2 Pembelajaran 1 di SD Terangmas, Undaan. Dimana ketika guru mengajar terlihat banyak siswa yang kurang interaktif saat pembelajaran. Banyak guru yang belum menggunakan media pembelajaran yang mengasyikkan.

Hasil pengamatan guru pada pembelajaran Tema 4 Subtema 2 Pembelajaran 1 dari 14 siswa hanya 4 anak (30\%) yang memenuhi kriteria ketuntasan minimal. Sebagai guru yang profesional merasa termotivasi untuk melakukan perbaikan, untuk meningkatkan minat belajar siswa. Upaya perbaikan yang peneliti lakukan dengan mengadakan Peneltian Tindakan Kelas (PTK).

Permasalahan tersebut diduga karena : (1) Guru belum menggunakan metode pembelajaran tematik yang bervariasi (2) Kelemahan guru dalam pembuatan dan pemanfaatan media pembelajaran (3) Kurangnya minat siswa dalam mengikuti pembelajaran (4) Kurannya daya dukung orang tua dan lingkungan terhadap pelaksanaan pembelajaran.

Untuk mengatasi kendala tersebut, maka penulis mecoba melakukan perbaikan pembelajaran menggunakan media powerpoint pembelajaran. Menurut Riski Ilham (2004: 18), powerpoint adalah program aplikasi yang berfungsi untuk membuat presentasi dalam bentuk slide-slide.

Berdasarkan uraian diatas, penulis akan mencoba melakukan penelitian dengan judul Peningkatan Hasil Belajar Berbagai Pekerjaan melalui Media Powerpoint pada Peserta Didik Kelas IV SD Terangmas.

Tujuan penelitian ini adalah meningkatkan hasil belajar siswa pada materi Tema 4 Sub Tema 2 Pembelajaran 1

\section{METODE}

Penelitian ini merupakan penelitian tindakan kelas (PTK) kolaboratif yang dilaksanakan dalam dua siklus, setiap siklus terdiri dari tahap perencanaan, pelaksanaan, observasi, dan refleksi. Subjek penelitian ini adalah peserta didik kelas IV di SD Terangmas Tahun Pelajaran 2020/2021 yang berjumlah 14 peserta didik.

Data yang dianalisis berupa data kualitatif yaitu penggunaan media powerpoint pembelajaran dan data kuantitatif yaitu hasil belajar tematik peserta didik. Teknik pengumpulan data menggunakan observasi dan tes. Uji validitas data menggunakan triangulasi teknik dan triangulasi sumber. Analisis data meliputi reduksi data, penyajian data, dan penarikan kesimpulan. 
HASIL DAN PEMBAHASAN

Berdasarkan analisis hasil penelitian yang telah diuraikan maka pembahasan pada penelitian ini sebagai berikut..

1. Penggunaan Media Powerpoint Pembelajaran

Hasil penelitian menunjukkan peningkatan penggunakan powerpoint pembelajaran yang dilakukan oleh guru. Terilhat pada tabel berikut.

Tabel 1. Peningkatan Penggunakan Media Vidio Pembelajaran

\begin{tabular}{|c|c|c|c|}
\hline Aspek & Skor Ra & rata & \\
\hline & Siklus I & Siklus II & Siklus III \\
\hline $\begin{array}{l}\text { Membuka pelajaran (ketrampilan membuka } \\
\text { pelajaran) }\end{array}$ & 2 & 3 & 3 \\
\hline $\begin{array}{l}\text { Menjelaskan materi pelajaran dengan media } \\
\text { powerpoint (ketrampilan menjelaskan) }\end{array}$ & 3 & 3 & 3 \\
\hline Bertanya (ketrampilan bertanya) & 2 & 3 & 3 \\
\hline $\begin{array}{l}\text { Membagi kelas ke dalam beberapa kelompok } \\
\text { (keterampilan mengelola kelas) } \\
\text { Membimbing siswa untuk merangkum materi } \\
\text { pembelajaran dan bergantian membacakan }\end{array}$ & 3 & 3 & 3 \\
\hline $\begin{array}{l}\text { hasil rangkuman kepada pasangannya } \\
\text { (keterampilan mengajar kelompok kecil dan } \\
\text { perorangan, membimbing diskusi dan } \\
\text { kelompok kecil) }\end{array}$ & 2 & 2 & 3 \\
\hline $\begin{array}{l}\text { Mengajarkan materi dengan menggunakan } \\
\text { media } \\
\text { powerpoint(ketrampilan mengadakan variasi) }\end{array}$ & 3 & 3 & 3 \\
\hline $\begin{array}{l}\text { Membimbing jalannya diskusi dengan } \\
\text { menerapkan model pembelajaran cooperative } \\
\text { learning (keterampilan membimbing diskusi } \\
\text { kelompok kecil) }\end{array}$ & 2 & 2 & 3 \\
\hline $\begin{array}{l}\text { Memberi penguatan (ketrampilan memberi } \\
\text { penguatan) }\end{array}$ & 2 & 2 & 3 \\
\hline $\begin{array}{l}\text { Menutup pelajaran (keterampilan menutup } \\
\text { pelajaran) }\end{array}$ & 2 & 3 & 3 \\
\hline
\end{tabular}

Dari data observasi yang diperoleh pada tabel di atas bahwa aktivitas mengajar atau kegiatan mengajar guru (peneliti) mengalami peningkatan dari siklus I ke siklus II hingga Siklus III.

2. Hasil Belajar pada materi rumus dan fungsi Microsoft excel

Hasil penelitian menunjukkan peningkatan hasil belajar pada materi Tema 4 Sub Tema 2 Pembelajaran ke-1. Terilhat pada tabel berikut.

Tabel 2. Peningkatan Hasil Belajar Siswa

\begin{tabular}{|c|c|c|c|}
\hline Nilai & \multicolumn{2}{|c|}{ Jumlah Siswa } & \\
\hline & Siklus I & Siklus II & Siklus III \\
\hline 100 & 0 & 0 & 1 \\
\hline 90 & 0 & 3 & 4 \\
\hline 80 & 4 & 4 & 7 \\
\hline 70 & 2 & 2 & 2 \\
\hline 60 & 4 & 5 & 0 \\
\hline 50 & 4 & 0 & 0 \\
\hline
\end{tabular}


SHEs: Conference Series 3 (3) (2020) 607-611

\begin{tabular}{llll} 
Jumlah & 14 & 14 & 14 \\
Rata-rata & 65 & 74 & 83 \\
Tuntas & 6 & 9 & 14 \\
\hline
\end{tabular}

Peningkatan hasil belajar tematik peserta didik pada materi Tema 4 Sub Tema 2 Pembelajaran 1 diukur dengan menggunakan teknik tes hasil belajar dengan instrument soal evaluasi menggunakan google form. Teknik pengumpulan data hasil belajar peserta didik diterapkan disetiap pertemuan setelah dilakukan proses pembelajaran.

Penggunaan media Powerpoint pembelajaran dapat meningkatkan hasil belajar peserta didik di kelas IV SD Terangmas secara signifikan. Pada hasil Penilaian sebelumnya terdapat 10 dari 14 peserta didik yang belum mencapai KKM dengan persentase ketuntasan hasil belajar hanya 30\%. Setelah dilakukan tindakan, persentase ketuntasan hasil belajar pada siklus I meningkat menjadi $43 \%$. Pada siklus II terjadi peningkatan kembali menjadi $64 \%$ dan siklus ke III mencapai $100 \%$. Pada siklus I belum mencapai indikator kinerja penelitian yang ditetapkan. Hasil belajar pada siklus I telah mencapai indikator kinerja penelitian dan terus meningkat pada siklus II. Pada siklus III, ketuntasan hasil belajar peserta didik telah mencapai $100 \%$ dengan KKM 70 sehingga pelaksanaan tindakan dapat dihentikan.

Berdasarkan analisis hasil belajar peserta didik setelah pelaksanaan tindakan, dapat diambil kesimpulan bahwa penggunaan media Powerpoint pembelajaran dapat meningkatkan hasil belajar tematik pada materi Tema 4 Sub Tema 2 Pembelajaran ke 1. Hal ini sesuai dengan hasil penelitian yang dilakukan oleh Aji Susilo, dan Afrinia Nur Fatimah yang membuktikan bahwa penggunaan media Powerpoint dalam pembelajaran tematik dapat meningkatkan hasil belajar siswa di SD secara signifikan

\section{SIMPULAN}

Uraian hasil Penelitian pada Penelitian Tindakan Kelas dan pembahasan pada bab sebelumnya yang berjudul Peningkatan Hasil Belajar Berbagai Pekerjaan melalui Media Powerpoint pada Peserta Didik Kelas IV SD Terangmas dapat diambil kesimpulan sebagai berikut:

(1) Dalam penelitian tindakan kelas ini peneliti meneliti tentang hasil belajar siswa.

(2) Hasil belajar siswa sebelum menggunakan Media Powerpoint pada Tema 4 Sub Tema 2 Pembelajaran 1 materi Berbagai Pekerjaan memiliki hasil belajar kelas dengan rata-rata sebesar 53 dengan ketuntasan kelas 30\%. Dalam hal ini hasil belajar peserta didik masih di bawah indikator keberhasilan dan ingin dilakukan perubahan.

(3) Berdasarkan hasil penelitian pada siklus I, siklus II, dan siklus III setelah diterapkannya Model Pembelajaran dengan menggunakan Media Powerpoint dapat meningkatkan hasil belajar peserta didik pada Tema 4 Sub Tema 2 Pembelajaran 1 materi Berbagai Pekerjaan di kelas IV SD Terangmas, Undaan, Kudus. Hal ini dapat dibuktikan dengan hasil belajar peserta didik yang meningkat setelah diterapkannya Model Pembelajaran menggunakan Media Powerpoint. Pada tahap Pra Siklus rata-rata hasil belajar 53 dengan ketuntasan klasikal 30\%. Pada Siklus I rata-rata 65 dengan ketuntasan klasikal 43\%. Pada Siklus II rata-rata 74 dengan ketuntasan klasikal mencapai $64 \%$. Dan pada siklus III Tuntas 100\% dengan rata-rata

\section{DAFTAR PUSTAKA}

Achmadi, Abu dan Cholid Narbuko, 2010. Metode Penelitian. Jakarta: Bumi Aksara.

Arikunto, S. (2013). Prosedur Penelitian: Suatu Pendekatan Praktik. Jakarta: Rineka Cipta.

Arikunto, Suhardjono, dan Supardi. 2015. Penelitian Pendidikan Kelas. Jakarta: Bumi Aksara 
Alamul Huda. (2007). Panduan Praktis Microsoft Powerpoint 2007. Surabaya: PenerbitIndah

Ashar Arsyad. (2002). Media Pembelajaran. Jakarta : PT. Raja Grafindo Persada Hamalik. (2001). Kurikulum dan Pembelajaran. Jakarta: Bumi Aksara.

Majid. (2004). Pembelajaran Tematik terpadu. Bandung: Remaja Rosda Karya. Oemar Riski Ilham (2004). Belajar Sendiri Langsung Praktek Microsoft Powerpoint 2002.Surabaya: Indah

Triyanto. 2010. Mengembangkan Model Pembelajaran Tematik. Jakarta: Prestasi Pustaka.

Wardhani, I. (2019). Penelitian Tindakan Kelas. Tanggerang: Universitas Terbuka 